ENTREPRENEURSHIP AND SUSTAINABILITY ISSUES

ISSN 2345-0282 (online) http://jssidoi.org/jesi/ 2021 Volume 9 Number 1 (September) http://doi.org/10.9770/jesi.2021.9.4126)

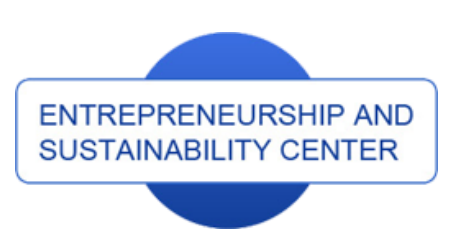

Publisher

http://jssidoi.org/esc/home enterprise

europe

network

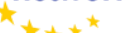

Business Support on Your Doorstep

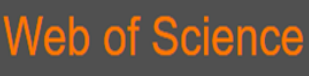

Clarivate

\title{
INTRODUCTION OF EEPSE GREEN ECONOMY INDEX FOR THE ANALYSIS OF REGIONAL TRENDS*
}

\author{
Oleg Rybalkin ${ }^{1}$, Olga Lavrinenko ${ }^{2}$, Svetlana Ignatjeva ${ }^{3}$, Alina Danileviča ${ }^{4}$ \\ 1,2,4 Daugavpils University, Institute of Humanities and Social Sciences, Parades Str. 1-421, Daugavpils, LV-5401, Latvia \\ ${ }^{3}$ Daugavpils University, Computer Science Department, Parades Str. 1-413, Daugavpils, LV-5401, Latvia \\ E-mails: ${ }^{1}$ oleg.rybalkin@gmail.com; ${ }^{2}$ olga.lavrinenko@du.lv; ${ }^{3}$ svetlana.ignatjeva@du.lv; ${ }^{4}$ alina.danilevica@du.lv
}

Received 15 March 2021; accepted 13 July 2021; published 30 September 2021

\begin{abstract}
The importance of analysing green economy has long been acknowledged by the international scientific community. Still there is strong demand for a comprehensive model which would serve as a scoreboard to assess a country's progress on green track and identify regional developments. Having dwelled upon this task, this article suggests using an original method - so called EEPSE Green Economy Index (which combines educational, economic, political, societal and environmental indicators), based on the Quintuple Helix Model, to analyse green economy trends in the EU countries. The results of the present study advocate the efficiency of such a tool and show its potential in performing current analysis, as well as predicting future tendencies related to sustainable development.
\end{abstract}

Keywords: green economy; Quintuple Helix model; sustainable development; EEPSE; Green Economy Index

Reference to this paper should be made as follows: Rybalkin, O., Lavrinenko, O., Ignatjeva, S., Danilevica, A. 2021. Introduction of EEPSE green economy index for the analysis of regional trends. Entrepreneurship and Sustainability Issues 9(1), 415-435. http://doi.org/10.9770/jesi.2021.9.1(26)

JEL Classifications: C43, O44, O52, O57, R11, Q20, Q30

\footnotetext{
* This article is published within the research project of Daugavpils University " Comparative analysis of the level of green economy development in Latvia and Lithuania from 2000 to 2020”, Nr. 14-95/2021/14
} 


\section{Introduction}

Scientific interest towards green economy has been growing constantly since the end of the 20th century and throughout the beginning of the 21st century - the period, which saw a series of global forums devoted environmental issues, mainly to global warming. Among the most important events "Earth Summit" in Rio De Janeiro (1992), Kyoto Protocol (1997), the Copenhagen Climate Change Conference (2009), Paris agreement on climate change (2015) etc. are to be mentioned. All these events marked significant stages in elaborating a strategy for sustainable development by both scholars and decision-makers. Sustainable development in general is a continuous process of satisfying needs of the present and future generations. The definition is unanimously accepted, alas ways of implementation of this approach towards development is under continuous discussion (Tvaronavičienè et al., 2015; Strielkowski et al., 2016; Tvaronavičienė, 2017; Razminienė, Tvaronavičienė, 2018; Eddelani et al., 2019).

In Europe this issue received an additional impetus with the adoption of European Green Deal (presented on 11 December 2019) -a roadmap with actions to boost the efficient use of resources by moving to a clean, circular economy, restore biodiversity and cut pollution.

Achieving such ambitious goals goes in line with the development of green economy in European countries. Still, scholars and policymakers seem to lack an efficient instrument to measure a country's record on this track, and to draw comparison between groups of states. In line with existing and commonly acknowledged by scientific community indexes such as The Global Green Economy Index (GGEI), The Green Growth Index (GGI), The Global Green Finance Index (GGFI), Environmental Performance Index (EPI), whose components were used in the present study, this article aims to work out a new Green Economy Index based on the Quintuple Helix model, which would take into account educational, economic, political, social and environmental aspects of the phenomenon. Thus it is proposed to call it EEPSE Green Economy Index. It is argued that with its help it's possible not only to measure EU27 + UK countries' performance with regard to green economy, divide them into main clusters, revealing divergence/convergence processes within these groups, but also analyse different political, economic and societal events related to sustainable development.

\section{Terms and definitions}

To highlight the multidisciplinary and multidimensional nature of the phenomenon the qualitative contentanalysis of definitions of various green concepts has been performed (see Table 1). In this type of analysis (specifically latent analysis) data are presented in words and themes, which makes it possible to draw some interpretation of the results, and the researcher seeks to find the underlying meaning of the text (Bengtsson, 2016). 


\section{ENTREPRENEURSHIP AND SUSTAINABILITY ISSUES}

ISSN 2345-0282 (online) http://jssidoi.org/jesi/ 2021 Volume 9 Number 1 (September)

http://doi.org/10.9770/jesi.2021.9.4126)

Table 1. Definitions of various green concepts

\begin{tabular}{|c|c|c|}
\hline Term & $\begin{array}{c}\text { The introducing entity, } \\
\text { year }\end{array}$ & Characteristics and definitions \\
\hline Green economy & Swart \& Groot, 2020 & $\begin{array}{l}\text { A green economy is one which is low carbon, is resource efficient, } \\
\text { and is socially inclusive... a green economy also comprehends the } \\
\text { design and implementation of specific policy instruments targeted at } \\
\text { the environment }\end{array}$ \\
\hline Green economy & Fulai, 2010 & $\begin{array}{l}\text { A green economy is typically understood as an economic system that } \\
\text { is compatible with the natural environment, is environmentally } \\
\text { friendly, is ecological, and for many groups, is also socially just }\end{array}$ \\
\hline Green growth & OECD, 2010 & $\begin{array}{l}\text { Green growth means promoting economic growth while reducing } \\
\text { pollution and greenhouse gas emissions, } \underline{\text { minimising waste and }} \\
\text { inefficient use of natural resources, and maintaining biodiversity. } \\
\text { Green growth means improving health prospects for populations and } \\
\text { strengthening energy security through less dependence on imported } \\
\text { fossil fuels. It also means making investment in the environment as a } \\
\text { driver for economic growth }\end{array}$ \\
\hline Green innovation & $\begin{array}{l}\text { Leal-Millán \& Antonio, } \\
2020\end{array}$ & $\begin{array}{l}\text { Green innovations are all type of innovations that contribute to the } \\
\text { creation of key products, services, or processes to reduce the harm, } \\
\text { impact, and deterioration of the environment at the same time that } \\
\text { optimizes the use of natural resources... and channel an appropriate } \\
\text { use of the natural resources to improve the human well-being .... } \\
\text { which could contribute to sustainable development. }\end{array}$ \\
\hline Green innovation & $\begin{array}{l}\text { Kemp \& Pearson, } 2007 \\
\text { (MEI project for the } \\
\text { European Commission) }\end{array}$ & $\begin{array}{l}\text { the production, assimilation or exploitation of a product, production } \\
\text { process, service or management or business method that is novel to } \\
\text { the organization (developing or adopting it) and which results, } \\
\text { throughout its life cycle, in a reduction of environmental risk, } \\
\text { pollution and other negative impacts of resources use (including } \\
\text { energy use) compared to relevant alternatives }\end{array}$ \\
\hline
\end{tabular}

Source: examination of existing bibliography

As it can be seen from the definitions above (keywords are underlined), the aspects of the phenomenon include education ("novel methods", "assimilation"), economy ("creation of products, goods and services", "economic system"), politics ("organizational structures" and "institutional arrangements"), society ("to improve the human well-being", "socially just", "for many groups") and natural environment ("environmental improvements", "ecological", "biodiversity"). This fact provides grounds for applying the Quintuple Helix model to its analysis.

\section{Methodology}

The Quintuple Helix model, which is used as basis for the EEPSE Green Economy Index, has several features. First, it is one of the models based on the quality management of effective development, restoring balance with nature and preserving Earth's biological diversity. As Barth (Barth, 2011) puts it, this model can solve existing problems by applying knowledge and know-how, as it focuses on the social (public) exchange and transfer of knowledge within the subsystems of a particular state or a national state. Second, the innovative Quintuple Helix model explains the way knowledge, innovations, and environment (natural environment) are interrelated (Carayannis and Campbell, 2010; Barth, 2011). The Quintuple Helix model is both interdisciplinary and 
transdisciplinary: the complexity of the five-spiral framework implies that a full analytical understanding of all spirals requires the continuous involvement of the entire disciplinary spectrum, ranging from Natural Sciences (due to inclusion of the natural environment) to Social Sciences and Humanities, to promote and visualize the system of collaboration between knowledge, know-how, and innovations for more sustainable development (Carayannis and Campbell, 2010). A visualized description of the model can be seen at Fig.1:

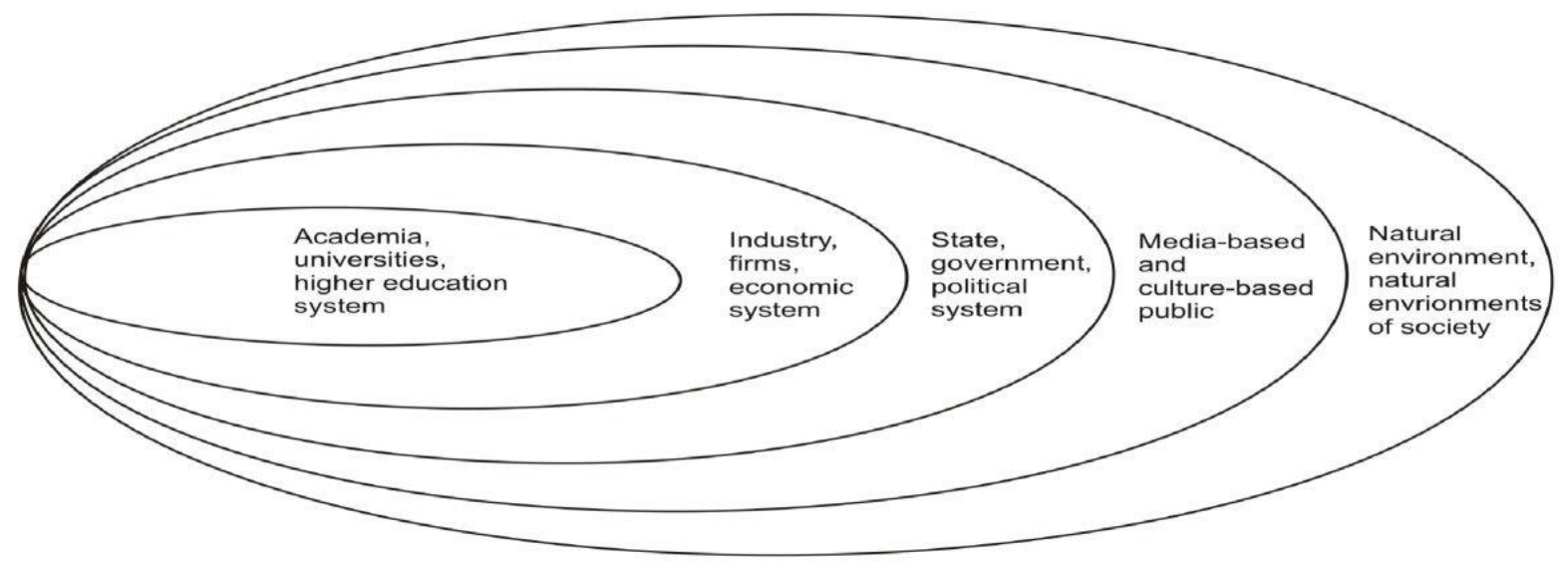

Figure 1. The subsystems of the Quintuple Helix model.

Source: Carayannis et al. 2012.; Etzkowitz and Leydesdorff 2000; Carayannis and Campbell, 2009, 2010.

As it is described at the figure, the first subsystem of this model is education, which forms the necessary "human capital". The second - economy -focuses on the "economic capital" (namely resource productivity, energy production and consumption, sustainable entrepreneurship etc). The third subsystem - politics - i.e. "political and legal capital" (in our context it refers to environmental regulations, taxes, international treaties etc.). The fourth subsystem - societal - unites the "social" and the "information" capital (it includes, for instance, green economy perception, press freedom, level of democracy etc). Finally, the fifth subsystem - environment (e.g. biodiversity, pollution etc.) provides society with the "natural capital".

All subsystems in the Quintuple Helix, as it can be seen at Figure 2, perform functions which influence each other (Ibid). In the innovative Quintuple Helix model, the natural environment is defined as an opportunity for further development and provision of sustainable development and co-evolution of the knowledge economy, knowledge society and democracy, which also influences the way we perceive and organise entrepreneurship (Etzkowitz and Leydesdorff 2000; Carayannis and Campbell, 2006, 2009, 2010; Barth, 2011; Aleksejeva et al., 2020). 


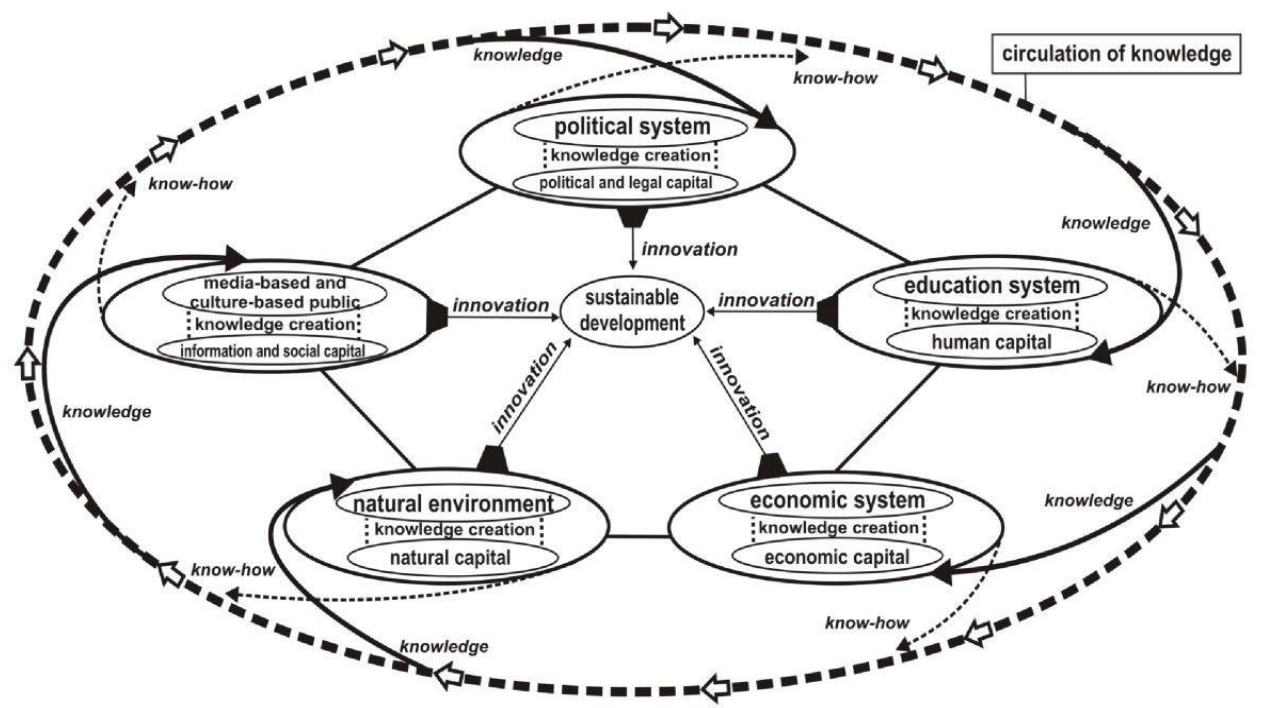

Figure 2. The Quintuple Helix model and its functions.

Source: Lavrinenko et al., 2019, by Carayannis et al. 2012

Now that the use of the Quintuple Helix has been substantiated, it seems reasonable to define specific indicators related to green economy. Previously a similar task was accomplished by the authors of this paper in 2019 (O. Lavrinenko et al., 2019), and the results of that study were taken as basis. Still, this time the set of all available statistical and integrated indicators corresponding to the Quintuple Helix model in the EU countries, which comprised the empirical base of the research, has been updated and broadened, so that each of the subsystems is represented by ten indicators (which makes 50 indicators in total). New indicators have been added (see Appendix 1), the technique has been improved.

All indicators were standardized, and then, in order to perceive them better, the transition to $\mathrm{T}$ scale by the formula $\mathrm{T}=50+10^{*} \mathrm{z}$ was made. Factors corresponding to the Quintuple Helix model are obtained as arithmetic means of the corresponding indicators; the integrated indicator is obtained as the arithmetic mean of the values of five subsystems. Hereinafter the overall indicator it is called EEPSE Green Economy Index.

Yet the feature of this paper is that it also seeks to test the potential of the proposed Index in analysing and foreseeing different political, economic and societal events related to green innovation and sustainable development. Particularly, in the present article it is applied to plug-in electric vehicle market share in the EU countries in 2020 .

\section{Research results}

According to the results of the research, Sweden became the leader of the list of the EU countries with EEPSE Green Economy Index equalling 58,97. The second place was taken by the United Kingdom $(58,14)$. At the same time Denmark $(57,75)$ outscored Germany $(56,42)$ in 2020 study. The top countries also include Finland $(56.02)$, France $(54,69)$ and the Netherlands (54.38).

As for the list of worst performers of the ranking, it includes Poland (43.21), Bulgaria (43.46), Cyprus (43.50), Hungary (44.94) and Romania (45.25). These results generally correspond to those, obtained during the first stage of the research (O. Lavrinenko et al., 2019). 
The cluster analysis was carried out in the five-factor EEPSE space. With the help of this pattern all EU countries were grouped into two homogeneous clusters (see Map, Figure 3). The first cluster (Cluster +, Table 4) includes countries which are characterized by higher value of indicators according to all five subsystems; other countries (Cluster -, Table 5) are characterized by a lower level of these indicators. The importance of predictors was as follows: 1-st political factor (the most important); 2-nd education; 3-rd society; 4-th environment; 5-th economy (the least important). This fact appears to be very interesting, since economy has the least importance when defining clusters, while politics plays the most important role.

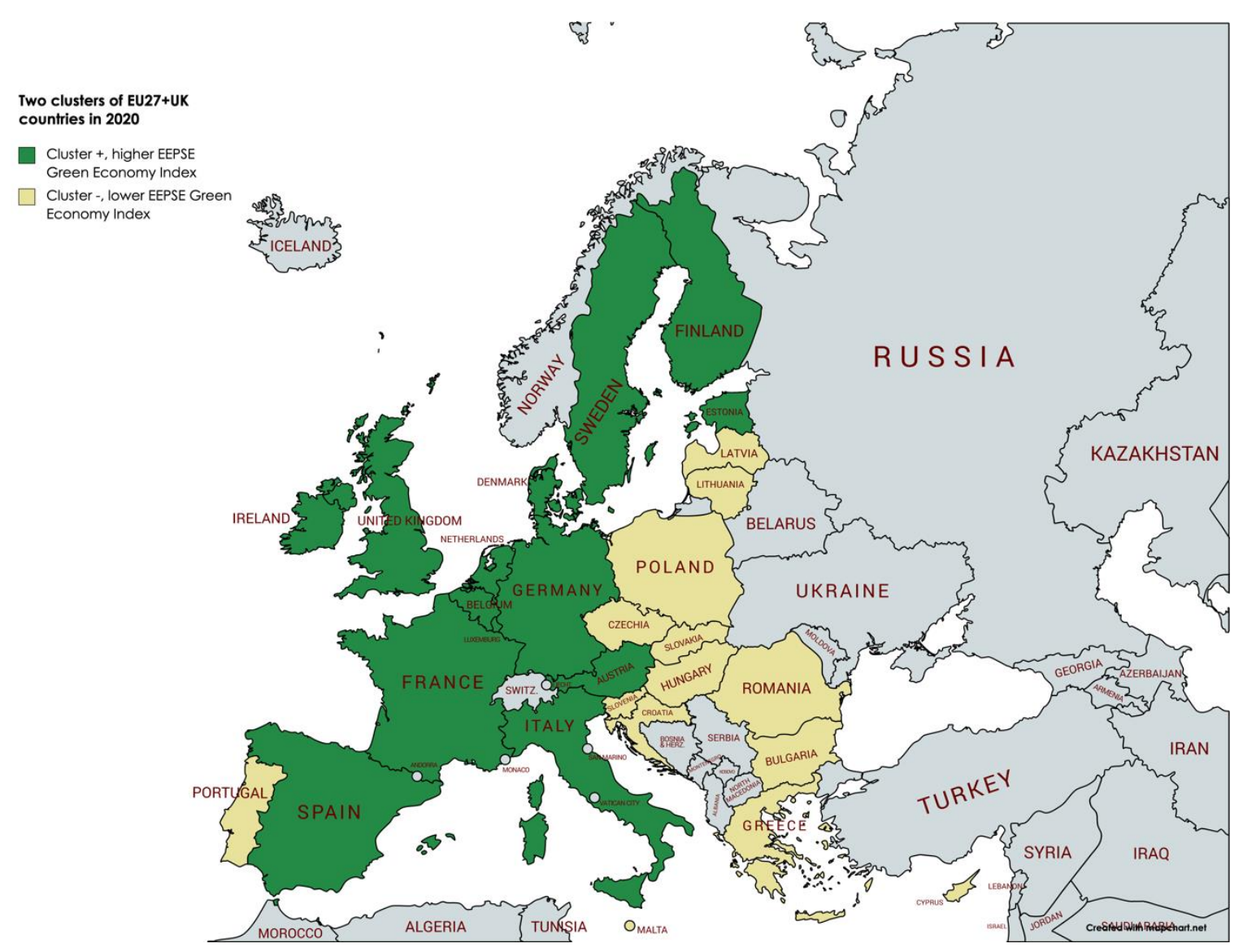

Figure 3. The EU countries plus UK divided into CL+, CL- clusters of a five-factor space of the Quintuple Helix model's subsystems in 2020

Source: the authors `calculations in SPSS according to statistical data

Considering the mean values of the subsystems in two clusters, it can be concluded that, as well as during the first stage of the research, all mean values of subsystems in the CL+ cluster exceed the mean values of subsystems in the CL- cluster. Particularly, the mean value of the "quality of education system" subsystem by $27 \%$, of the "political" subsystem by $18.5 \%$, of the "civil society" subsystem by $14.3 \%$, of the "economic aspects" subsystem by $14.2 \%$, of the "natural environment" subsystem by $11.3 \%$, (see Figure 4 ): 


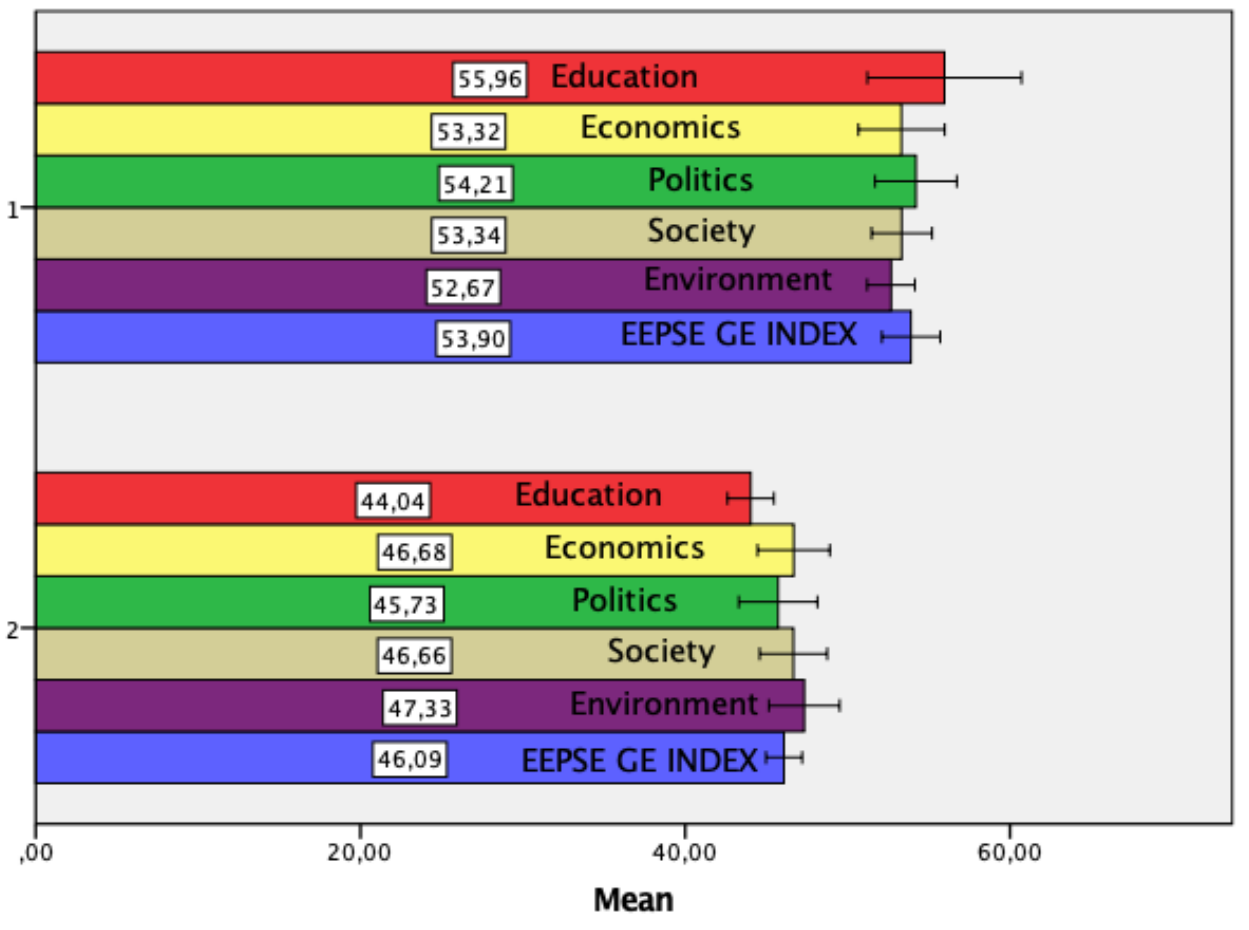

Figure 4. Comparison of Cluster + (1) and Cluster - (2).

Source: the authors ' calculations in SPSS according to statistical data

As it has already been stated, Sweden became the leader by the EEPSE Green Economy Index in Cluster + (see Table 2 below), while the place in the bottom of this group is now occupied by the newcomer (as compared with the first stage of the research) - Ireland. The United Kingdom confirmed its leading positions in the educational subsystem (71.52), while another debutant of Cluster + Estonia showed the lowest academia record among the leaders (44.28). Sweden again became the leader in the economic subsystem (64.58), while Belgium is located at the bottom of the list (46.91). Sweden also has shown the best results in the "Civil society" $(58,45)$ subsystem, while in the sphere of politics it yielded palm to Denmark $(61,73)$ and Finland $(60,92)$. Speaking of the "Natural environment" subsystem, Denmark scored the most (55.38) and Belgium - the least (47.85). 
Table 2. Values of the cluster CL+ Quintuple Helix model's subsystems in 2020, EEPSE GEI descending

\begin{tabular}{|c|c|c|c|c|c|c|c|}
\hline № & Country name & $\begin{array}{c}\text { Quality of education } \\
\text { system }\end{array}$ & $\begin{array}{l}\text { Economic } \\
\text { aspects }\end{array}$ & $\begin{array}{l}\text { Political } \\
\text { system }\end{array}$ & $\begin{array}{c}\text { Civil } \\
\text { society }\end{array}$ & $\begin{array}{c}\text { Natural } \\
\text { environment }\end{array}$ & $\begin{array}{c}\text { Mean= } \\
\text { EEPSE } \\
\text { GEI }\end{array}$ \\
\hline 1 & Sweden & 57,39 & 64,58 & 59,59 & 58,45 & 54,83 & 58,97 \\
\hline 2 & United Kingdom & 71,52 & 57,00 & 56,36 & 51,33 & 54,51 & 58,14 \\
\hline 3 & Denmark & 55,42 & 59,56 & 61,73 & 56,65 & 55,38 & 57,75 \\
\hline 4 & Germany & 69,28 & 51,72 & 54,71 & 51,28 & 55,09 & 56,42 \\
\hline 5 & Finland & 53,08 & 56,02 & 60,92 & 57,32 & 52,73 & 56,02 \\
\hline 6 & France & 63,88 & 51,41 & 54,06 & 50,47 & 53,64 & 54,69 \\
\hline 7 & Netherlands & 58,33 & 51,71 & 56,45 & 53,86 & 51,55 & 54,38 \\
\hline 8 & Austria & 52,37 & 52,67 & 51,22 & 50,35 & 54,48 & 52,22 \\
\hline 9 & Luxembourg & 44,93 & 51,78 & 53,31 & 55,92 & 54,77 & 52,14 \\
\hline 10 & Spain & 57,32 & 48,43 & 47,83 & 51,36 & 51,90 & 51,37 \\
\hline 11 & Estonia & 44,28 & 52,62 & 51,21 & 54,42 & 52,83 & 51,07 \\
\hline 12 & Italy & 56,68 & 50,12 & 50,19 & 47,16 & 49,96 & 50,82 \\
\hline 13 & Belgium & 52,84 & 46,91 & 52,60 & 52,54 & 47,85 & 50,55 \\
\hline 14 & Ireland & 46,19 & 51,91 & 48,77 & 55,59 & 47,92 & 50,08 \\
\hline \multicolumn{8}{|c|}{ CL5 = CL+ } \\
\hline
\end{tabular}

Source: the authors' calculations in SPSS according to statistical data

Investigating the situation in the Cluster - (see Table 3), it has to be mentioned that certain differences in countries' positions have occurred here as well. As it has already been stated above, the countries with high scores which previously were in this group have managed to move to Cluster + . As a result, Cluster - group in 2020 included 14 (not 21) countries, with Slovenia $(48,59)$ as a leader and Poland $(43,21)$ as an underdog in terms of EEPSE GEI.

It is worth mentioning that Latvia secured strong positions in the top of the Cluster - , with overall performance being better than the one of neighboring Lithuania, and the best record in the economic subsystem among Cluster - countries, but weak educational indicators: 
Table 3. Values of the cluster CL- Quintuple Helix model's subsystems in 2020, EEPSE GEI ascending

\begin{tabular}{|c|c|c|c|c|c|c|c|}
\hline No & Country name & $\begin{array}{c}\text { Quality } \\
\text { of education } \\
\text { system }\end{array}$ & $\begin{array}{c}\text { Economic } \\
\text { aspects }\end{array}$ & $\begin{array}{c}\text { Political } \\
\text { system }\end{array}$ & $\begin{array}{c}\text { Civil } \\
\text { society }\end{array}$ & $\begin{array}{c}\text { Natural } \\
\text { environment } \\
\text { EEPSE GEI }\end{array}$ \\
\hline 1 & Poland & 47,55 & 40,72 & $\mathbf{3 7 , 5 0}$ & 44,68 & 45,61 & $\mathbf{4 3 , 2 1}$ \\
\hline 2 & Bulgaria & 42,24 & 43,40 & 42,14 & 42,67 & 46,85 & 43,46 \\
\hline 3 & Cyprus & 42,52 & $\mathbf{4 0 , 3 4}$ & 43,57 & 51,63 & $\mathbf{3 9 , 4 2}$ & 43,50 \\
\hline 4 & Hungary & 45,15 & 45,42 & 43,57 & 42,76 & 47,83 & 44,94 \\
\hline 5 & Romania & 42,17 & 49,09 & 43,06 & 42,91 & 49,02 & 45,25 \\
\hline 6 & Malta & 42,52 & 49,82 & 43,70 & 47,28 & 43,98 & 45,46 \\
\hline 7 & Croatia & 42,32 & 49,50 & 45,24 & $\mathbf{4 0 , 8 5}$ & 49,76 & 45,53 \\
\hline 8 & Slovakia & 42,33 & 46,92 & 45,58 & 44,98 & 49,93 & 45,95 \\
\hline 9 & Czech Republic & 46,65 & 45,69 & 44,54 & 48,10 & 50,69 & 47,13 \\
\hline 10 & Greece & 47,26 & 42,15 & 48,31 & $\mathbf{5 1 , 8 8}$ & 48,40 & 47,60 \\
\hline 11 & Lithuania & 41,58 & 51,32 & 47,93 & 48,68 & 49,61 & 47,82 \\
\hline 12 & Latvia & $\mathbf{4 0 , 9 0}$ & $\mathbf{5 2 , 2 3}$ & 51,79 & 48,16 & 48,37 & 48,29 \\
\hline 13 & Portugal & $\mathbf{4 7 , 6 7}$ & 49,08 & $\mathbf{5 3 , 7 3}$ & 51,35 & 40,53 & 48,47 \\
\hline 14 & Slovenia & 45,63 & 47,89 & 49,50 & 47,36 & $\mathbf{5 2 , 5 8}$ & $\mathbf{4 8 , 5 9}$ \\
\hline & & & & & \\
\hline
\end{tabular}

Source: the authors' calculations in SPSS according to statistical data

\section{Investigating green economy trends in the European Union}

As the present research has been performed in three stages (approximately 4 years of observations), the data collected through this period of time were systematised and analysed to find out if there have been convergence or divergence trends in terms green economy development in the EU countries. Such analysis was applied both to overall EEPSE Green Economy Index and its components in the period of 2017-2020.

To reveal the tendencies the sigma convergence for data throughout the three stages of the research was tested. The indicator $-\sigma$ - shows the convergence and divergence tendency depending on the value of sample variance.

Such approach has been widely used by scholars in relation to the economy of the EU. Simionescu (2014), for instance, utilizes it to measure the evolution of real convergence process between the EU countries in terms of GDP per capita in 2000 and 2012. Sometimes such an approach is also used to assess convergence and divergence processes across old and new members of the European Union.

Speaking of the present research, the variation is measured for factors and overall Green Economy Index using simple indicator (the mean) and synthetic indicators (variance, standard deviation, and coefficient of variation).

In a dynamic analysis the variation in decrease allows us to conclude the existence of a more obvious convergence process. And just the reverse - variation in increase signals about the existence of a more obvious divergence process. At the same time, the most useful indicator is the coefficient of variation, because it allows to make necessary comparisons and conclusions.

The variance for different factors of green economy and its overall index in the EU $27+$ UK countries was computed as: 
ENTREPRENEURSHIP AND SUSTAINABILITY ISSUES

ISSN 2345-0282 (online) http://jssidoi.org/jesi/ 2021 Volume 9 Number 1 (September) http://doi.org/10.9770/jesi.2021.9.4126)

$$
\sigma^{2}=\frac{\sum_{i=1}^{2 g}\left(x_{1}-x\right)^{2}}{28}
$$

where $x_{i}-$ the variable, $\mathrm{i}-$ index for countries (1-28), $\bar{x}-$ simple arithmetic average: $\bar{x}=\frac{\sum_{i=1}^{28} x_{i}}{28}$.

The variance expresses the degree of variation of the values compared to the average. It is affected by outliers and by the variable measurement of unit. The variance is also used to calculate the standard deviation $\left(\sigma=\sqrt{\sigma^{2}}\right)$ and the coefficient of variation $\left(C V=\frac{\sigma}{g}\right)$, the last one expressing in a relative form the variation compared to average.

The indicator $(\sigma)$ is used to characterize the level of convergence by measuring the variance of EEPSE Green Economy Index and its components for three stages of the research, utilizing the cross- section data about EU27 + UK countries. The indicator is relevant when comparisons are made. For describing the convergence tendency, time series are used on a discrete interval from $t$ to $t+T$. In a certain time period when the variance of the variable decreases (the indicator value decreases in time), the convergence process took place: $\sigma_{t}<\sigma_{t+\pi}$. When the variance grows, the divergence process took place: $\sigma_{t}>\sigma_{t+T}$.

In the first place the $\sigma$-convergence was tested for all countries under analysis regardless of the clusters (see Table 4). The results show that there is a convergence process in terms of overall EEPSE Green Economy Index in the EU countries. As it can be seen from the data in the Table, it can be attributed to convergence in the sphere of society, while coefficients of variation in the spheres of education and economy remain approximately the same.

Table 4. Comparison of indicators through three stages of the research (all countries)

\begin{tabular}{|c|c|c|c|c|c|c|c|}
\hline \multicolumn{2}{|l|}{ Year } & $\begin{array}{l}\text { Factor 1- } \\
\text { Education }\end{array}$ & $\begin{array}{l}\text { Factor } 2 \text { - } \\
\text { Economy }\end{array}$ & $\begin{array}{l}\text { Factor 3 - } \\
\text { Politics }\end{array}$ & $\begin{array}{l}\text { Factor } 4- \\
\text { Society }\end{array}$ & $\begin{array}{l}\text { Factor } 5 \\
- \\
\text { Environment }\end{array}$ & $\begin{array}{l}\text { EEPSE } \\
\text { Green } \\
\text { Econony } \\
\text { Index }\end{array}$ \\
\hline \multirow{4}{*}{$\begin{array}{l}2017- \\
2018\left(1^{\text {st }}\right. \\
\text { research } \\
\text { stage })\end{array}$} & Mean & 50 & 50 & 50 & 50 & 50 & 50 \\
\hline & Variance & 73,243 & 22,135 & 35,932 & 77,439 & 13,276 & 27,864 \\
\hline & $\begin{array}{l}\text { Std. } \\
\text { deviation }\end{array}$ & 8,55821 & 4,70479 & 5,99437 & 8,79993 & 3,64367 & 5,27866 \\
\hline & $\begin{array}{l}\text { Coefficient } \\
\text { of variation } \\
(\%)\end{array}$ & $17,1 \%$ & $9,4 \%$ & $12 \%$ & $17,6 \%$ & $7,2 \%$ & $10,6 \%$ \\
\hline \multirow{4}{*}{$\begin{array}{l}2019\left(2^{\text {nd }}\right. \\
\text { research } \\
\text { stage })\end{array}$} & Mean & 50 & 50 & 50,0096 & 50 & 49,9411 & 49,9901 \\
\hline & Variance & 71,401 & 30,644 & 8,16 & 34,042 & 32,171 & 23,148 \\
\hline & $\begin{array}{l}\text { Std. } \\
\text { deviation }\end{array}$ & 8,44994 & 5,53571 & 2,8566 & 5,83452 & 5,67193 & 4,81121 \\
\hline & $\begin{array}{l}\text { Coefficient } \\
\text { of variation } \\
(\%)\end{array}$ & $17 \%$ & $11 \%$ & $5,7 \%$ & $11,7 \%$ & $11,4 \%$ & $9,6 \%$ \\
\hline \multirow{4}{*}{$\begin{array}{l}2020\left(3^{\text {rd }}\right. \\
\text { research } \\
\text { stage })\end{array}$} & Mean & 50 & 50 & 49,9679 & 50 & 50 & 49,9936 \\
\hline & Variance & 72,316 & 28,764 & 36,357 & 22,778 & 17,423 & 22,26 \\
\hline & $\begin{array}{l}\text { Std. } \\
\text { deviation }\end{array}$ & 8,50386 & 5,36324 & 6,02966 & 4,7726 & 4,1741 & 4,71806 \\
\hline & $\begin{array}{l}\text { Coefficient } \\
\text { of variation } \\
(\%)\end{array}$ & $17 \%$ & $10,7 \%$ & $12 \%$ & $9,5 \%$ & $8,3 \%$ & $9,4 \%$ \\
\hline
\end{tabular}

Source: the authors' calculations in SPSS according to statistical data 
At the same time, the situation in two clusters differs. As it can be seen in Table 5, overall EEPSE Green Economy Index converges within the framework of Cluster + . It can be attributed to the convergence process in the sphere of economy and society. At the same time, there is a clear divergence process in the educational sphere. It can be explained by the fact that countries with good record on this track (the UK, Germany, France) manage to preserve their leadership and even to increase their advantages as compared to countries with lower academic results (Ireland, Luxembourg, Estonia).

Table 5. Comparison of indicators through three stages of the research (Cluster +)

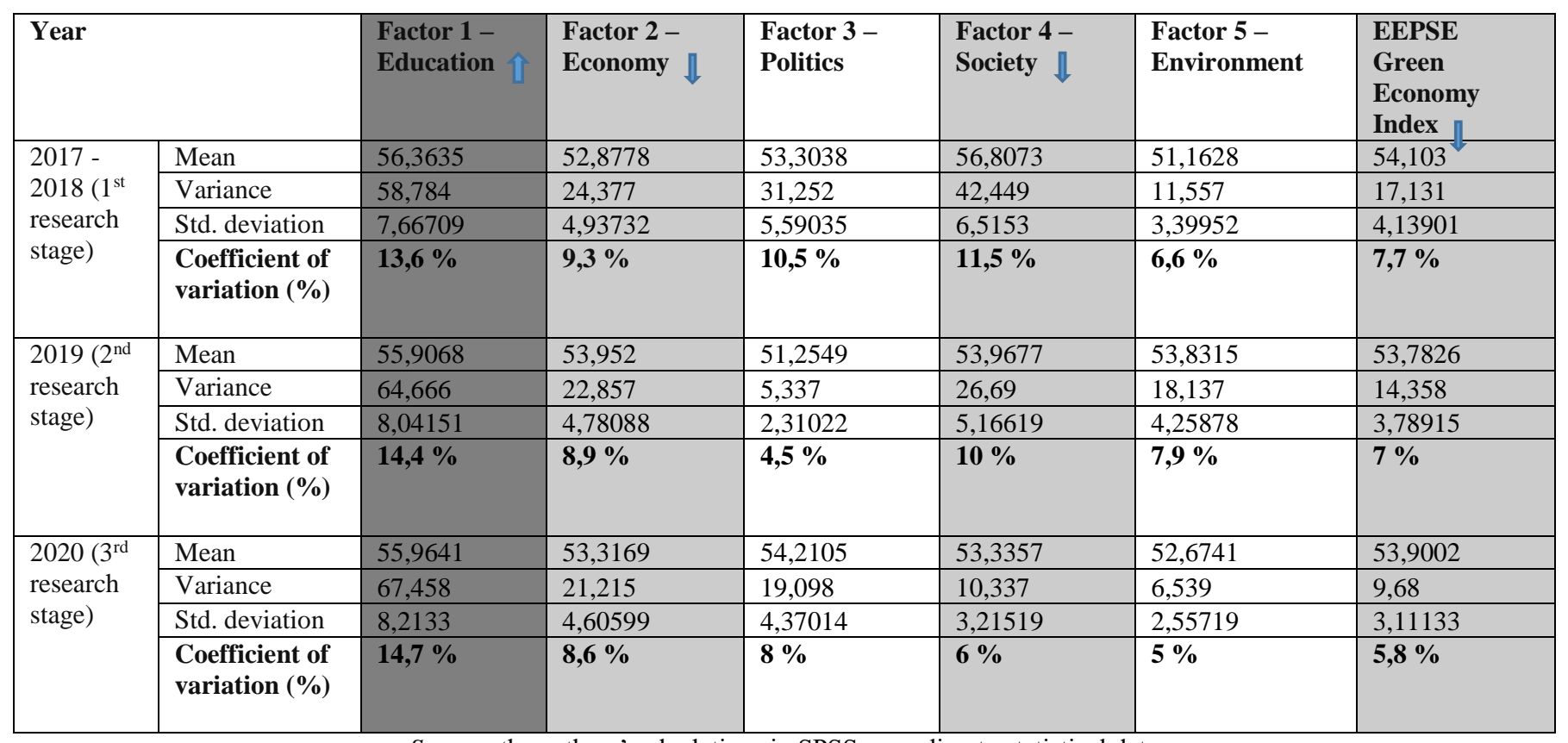

Source: the authors' calculations in SPSS according to statistical data

Moving on to the situation in Cluster -, it has to be mentioned that $\sigma$-divergence was confirmed in the sphere of economy of the 14 countries (see Table 6). 
Table 6. Comparison of indicators through three stages of the research (Cluster - )

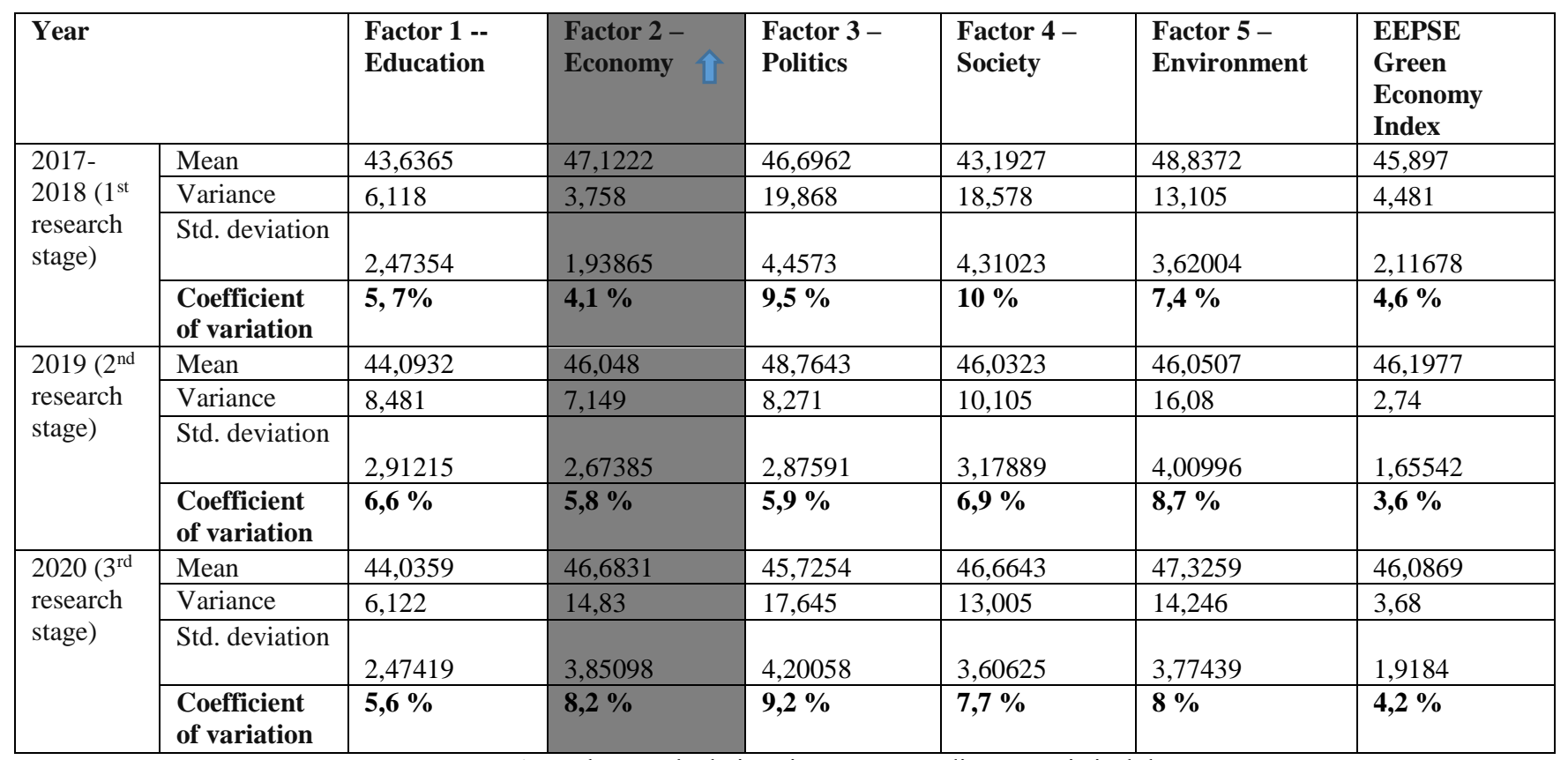

Source: the authors' calculations in SPSS according to statistical data

At this point the EEPSE Green Economy Index, based on Quintuple Helix model, provided an ability to define scores for the EU countries (plus the UK) and divide them into two clusters, as well as to trace divergence and convergence processes in terms of green economy through the three stages of research.

However, proposed model would gain additional value if it has potential in analysing or predicting political/societal/economic events related to green developments. The next chapter tests correlation of EEPSE Green Economy Index with the growth of plug-in electric car share in Europe in 2020.

\section{Correlation with economy: case of plug-in electric car share growth}

To test such correlation, it was decided to take the indicator of plug-in electric car market share in European countries in 2020. This year was remarkable since the average market share of new passenger plug-in electric cars in Europe more than tripled in this period of time to $11.4 \%$ (from less than $3.6 \%$ in 2019). Specialists name two reasons for that - unprecedented increase of plug-in vehicle sales, and decrease of conventional ICE car sales (Kane, 2021).

Data on such indicator was available for almost all EU27 + UK countries, except for Malta and Bulgaria (see Table 7): 
Table 7. Plug-in electric car share of market and EEPSE GEI of the EU countries in 2020

\begin{tabular}{|c|c|c|c|}
\hline № & Country name & $\begin{array}{c}\text { EEPSE GEI, } \\
\text { descending }\end{array}$ & $\begin{array}{c}\text { Passenger plug-in } \\
\text { electric car market } \\
\text { share, } 2020\end{array}$ \\
\hline 1 & Sweden & 58,97 & 0,322 \\
\hline 2 & United Kingdom & 58,14 & 0,107 \\
\hline 3 & Denmark & 57,75 & 0,164 \\
\hline 4 & Germany & 56,42 & 0,135 \\
\hline 5 & Finland & 56,02 & 0,181 \\
\hline 6 & France & 54,69 & 0,113 \\
\hline 7 & Netherlands & 54,38 & 0,249 \\
\hline 8 & Austria & 52,22 & 0,095 \\
\hline 9 & Luxembourg & 52,14 & 0,114 \\
\hline 10 & Spain & 51,37 & 0,048 \\
\hline 11 & Estonia & 51,07 & 0,023 \\
\hline 12 & Italy & 50,82 & 0,043 \\
\hline 13 & Belgium & 50,55 & 0,107 \\
\hline 14 & Ireland & 50,08 & 0,074 \\
\hline 15 & Slovenia & 48,59 & 0,031 \\
\hline 16 & Portugal & 48,47 & 0,135 \\
\hline 17 & Latvia & 48,29 & 0,028 \\
\hline 18 & Lithuania & 47,82 & 0,011 \\
\hline 19 & Greece & 47,6 & 0,026 \\
\hline 20 & Czech Republic & 47,13 & 0,026 \\
\hline 21 & Slovakia & 45,95 & 0,019 \\
\hline 22 & Croatia & 45,53 & 0,019 \\
\hline 23 & Malta & 45,46 & $\mathrm{n} / \mathrm{a}$ \\
\hline 24 & Romania & 45,25 & 0,022 \\
\hline 25 & Hungary & 44,94 & 0,047 \\
\hline 26 & Cyprus & 43,5 & 0,004 \\
\hline 27 & Bulgaria & 43,46 & $\mathrm{n} / \mathrm{a}$ \\
\hline 28 & Poland & 43,21 & 0,019 \\
\hline
\end{tabular}

From the list above it can already be observed that electric cars are sold better in countries with high EEPSE Green Innovation Index. This hypothesis was tested with SPSS software (see Table 8):

Table 8. Correlation of ECV market share in European countries with EEPSE GEI and its components

\begin{tabular}{|ll|c|c|c|c|c|c|}
\hline & & $\begin{array}{l}\text { GEI_ } \\
2020\end{array}$ & Education & Economy & Politics & Society & \multicolumn{1}{c|}{$\begin{array}{c}\text { Natural } \\
\text { environment }\end{array}$} \\
\hline $\begin{array}{l}\text { ECV_market_ } \\
\text { share }\end{array}$ & $\begin{array}{l}\text { Pearson } \\
\text { Correlation }\end{array}$ &, $790^{* *}$ &, $565^{* *}$ &, $716^{* *}$ &, $796^{* *}$ &, $672^{* *}$ &, $412^{*}$ \\
& Sig. (2-tailed) &, 000 &, 003 &, 000 &, 000 &, 000 &, 036 \\
& $\mathrm{~N}$ & 26 & 26 & 26 & 26 & 26 & 26 \\
& & & & & 26 \\
\end{tabular}

**. Correlation is significant at the 0.01 level (2-tailed).

*. Correlation is significant at the 0.05 level (2-tailed).

Source: the authors' calculations in SPSS according to statistical data 


\section{ENTREPRENEURSHIP AND SUSTAINABILITY ISSUES}

ISSN 2345-0282 (online) http://jssidoi.org/jesi/

2021 Volume 9 Number 1 (September)

http://doi.org/10.9770/jesi.2021.9.4126)

As it can be seen from the chart above, the correlation between EEPSE Green Economy Index and plug-in electric car market share in the EU countries in 2020 was $\mathbf{0 , 7 9 0}$ with a very high statistical significance (p-value 0.000), which can be characterized as very strong (classification by Political Science Department at Quinnipiac University, as cited from Akoglu 2018).

It is interesting that the strongest correlation is found with the sphere of politics $(\mathbf{0 , 7 9 6 )}$, not economy $(\mathbf{0 , 7 1 6})$. True, electric car sales can hardly be described as purely economic factor, since electrification of transport is quite a complicated phenomenon. Electric vehicles are still very expensive as compared with conventional analogues. Thus, to boost their popularity some subsidies and support from the state are needed, be it tax discounts, cheap credits, road and parking privileges etc. Relevant infrastructure, including charging stations, should be created. Such tasks definitely lay within the sphere of political system.

The calculations made in this paper present quite interesting results. Previously the differences in electric cars market share in various European countries have been attributed by specialists and manufacturers mostly to the gap in GDP per capita. For example, European Automobile Manufacturers' Association (2019) explained, that in 2018 all countries with an electrically charged vehicle (ECV) market share of less than $1 \%$ had a GDP below $€ 29,000$, including both new EU member states in Central and Eastern Europe, as well as Spain, Italy and Greece. By contrast, the manufacturers continue explaining, an ECV market share of above $3.5 \%$ only occurs in countries with a GDP per capita of more than $€ 42,000$.

Taking this into account specialists take the Norwegian market as a benchmark. They point to the fact that just like its $€ 73,200$ GDP per capita, more than twice the EU average $(€ 30,600)$ in 2018 , Norway's $49.1 \%$ ECV share was then exceptional for Europe.

At the same time, the countries that come second and third, Sweden (8\%) and the Netherlands (6.7\%), have some of the highest GDPs in the EU but much lower ECV market shares.

Having investigated these data, market-oriented specialists come to the conclusion that not only there is a clear split between Central-Eastern and Western Europe, but also a pronounced North-South divide in terms of electric transport development (European Automobile Manufacturers' Association, 2019).

Of course, such distinctions in economic indicators between different European countries cannot be underestimated. Particularly, while western and northern Europeans (conditionally, CL+) have well-developed and diversified economies and can concentrate on green shift, others members of the EU still need to ensure necessary infrastructure, acceptable level of income etc., to catch up with the levels of development in Western Europe. So, two groups of countries have no option but to place emphasis on dealing with different tasks. Second, shifting to a greener economy costs money, and leaders might nor be willing to dismiss a generation of workers (their electorate).

With all the truth about such observations concerning economic subsystem, such a market-centric approach seems to be quite one-sided and to some extent even primitive. Particularly, this view presupposes that proliferation of green technologies (in this case - electric cars) depends solely on economic prosperity.

Contrary to that, the EEPSE GEI model provides a better-balanced and multifactorial view on this phenomenon, which takes into account educational, economic, political, societal and environmental factors at the same time. The effectiveness of such an approach has been confirmed withing the present chapter. 


\section{ENTREPRENEURSHIP AND SUSTAINABILITY ISSUES}

ISSN 2345-0282 (online) http://jssidoi.org/jesi/

2021 Volume 9 Number 1 (September)

http://doi.org/10.9770/jesi.2021.9.4126)

\section{Discussion and conclusions}

Different integral indicators are widely used as a tool to describe the development of green growth. Attempts to make the assessment of green economy have been made by several researches and institutions. For example, Kasztelan (Kasztelan, 2017) used 33 selected indicators of green economy on the basis of the OECD methodologies and database to that end. Diagnostic variables defining the level of green growth for particular countries were adjusted in an attempt to meet three criteria: substantive, formal, and statistical. Based on the results obtained, the author concludes that the green growth can provide solutions to economic and environmental problems and create new sources for growth (Kasztelan, 2017), however, its level in the OECD countries is still insufficient (Ibid). In his research Kasztelan (2018), having examined the green growth level in 28 EU countries, applied the same methods and determined 4 groups of countries: Sweden (0.6477) is the leader (in this part the results of Kasztelan (Kasztelan, 2018) study are close to the present dissertation), followed by the countries from the second group (and in this part the results differ): Croatia (0.5668), Latvia (0.5447), Austria (0.5399), Finland (0.5383), the Netherlands (0.5249), Slovenia (0.4925), Denmark (0.4874), Hungary (0.4808), Belgium (0.4777), Italy (0.4722), and the United Kingdom (0.4666). Slovakia (0.4647), Lithuania (0.4589), Czech Republic (0.4570), Luxembourg (0.4538), Germany (0.4521), Portugal (0.4469), Spain (0.4461), Poland (0.4406), France (0.4336), Ireland (0.41), Estonia (0.4038), and Romania (0.4015) belong to the third group. The fourth group countries Greece (0.3913), Malta (0.3865), Bulgaria (0.3755), and Cyprus (0.3614) are at the bottom.

As it can be seen, Kasztelan (Kasztelan, 2018) divided the EU countries into four groups, contrary to two clusters found within the present article. It has to be mentioned again, that the OECD methodology (OECD 2017) which the scholar took as a basis, ignores the area of education, while the present paper assigns an important role to it.

The results and methodology of the present article can also be compared to the eco-innovation scoreboard and the eco-innovations index, which is aimed at capturing the different aspects of eco-innovation by applying 16 indicators grouped into five dimensions: eco-innovation inputs, eco-innovation activities, eco-innovation outputs, resource efficiency and socio-economic outcomes (Spaini, Markianidou and Doranova, 2018). The leaders according to this index are: Luxembourg (138 points), Germany (137 points), Sweden (132 points), Finland (121 points), Austria (119), Denmark (115); the worst performers are Cyprus (45), Bulgaria (50), Poland (59), Malta (59), Romania (66). Generally these results coincide with the outcome of the research performed by the authors of the present article. At the same time the differences may be caused by different methodology, because eco-innovation scoreboard places less emphasis on environmental and political issues and more on economy.

Therefore, there are both similarities in the assessment of the green economy presented in this paper and other studies, and differences, which can be affected (as well as by the methodology) by the time period, countries under research and indicators chosen. Key challenges of the indicator approach also include data availability, right balance between different indicator selection criteria, systemic understanding of the relationships between indicators, and the variable usage contexts of the indicators.

Still, the EEPSE Green Economy Index, presented within this paper - a set of policy-relevant key indicators based on Quintuple Helix model - proved usable for dealing with key green growth issues, analysing different countries" "green" performance and various economic, political and societal events related to green development. 


\section{ENTREPRENEURSHIP AND SUSTAINABILITY ISSUES}

ISSN 2345-0282 (online) http://jssidoi.org/jesi/ 2021 Volume 9 Number 1 (September)

http://doi.org/10.9770/jesi.2021.9.4126)

\section{References}

Akoglu, H. (2018). User's guide to correlation coefficients. Turkish Journal of Emergency Medicine, 18(3), 91-93. https://doi.org/10.1016/j.tjem.2018.08.001

Aleksejeva, L, Ostrovska, I. \& M.Aleksejevs (2020). A comprehensive place-based approach for smart growth in cross border territories. In: ACM International Conference Proceeding. Series DEFIN '20: Proceedings of the III International Scientific and Practical Conference. Article No. 36, pp. 1-4. https://doi.org/10.1145/3388984.3390645

Barth, T.D. (2011). The idea of a green new deal in a Quintuple Helix Model of knowledge, know-how and innovation. International Journal of Social Ecology and Sustainable Development, 1(2), 1-14.

Bengtsson, M. (2016). How to plan and perform a qualitative study using content analysis. NursingPlus Open, 2, 8-14. https://doi.org/10.1016/j.npls.2016.01.001.

Carayannis, E.G. (2011). Planet earth 2011 - global warming challenges and opportunities for policy and practice. Open Access Publisher. Retrieved from: https://www.intechopen.com/books/planet-earth-2011-global-warming-challenges-andopportunities-for-policy-and-practice

Carayannis, E. G., Barth, T. D. \& Campbell, D. F. J. (2012). The Quintuple Helix innovation model: global warming as a challenge and driver for innovation. Journal of Innovation and Entrepreneurship, 1 (2), 1-12. https://link.springer.com/article/10.1186/2192-5372-1-2

Carayannis, E. G., Barth, T. D. \& Campbell, D. F .J. (2012). The Quintuple Helix innovation model: global warming as a challenge and driver for innovation. Journal of Innovation and Entrepreneurship, 1 (2). Retrieved from: https://innovationentrepreneurship.springeropen.com/articles/10.1186/2192-5372-1-2

Carayannis, E. G. \& Campbell, D. F. J. (2009). "Mode 3" and "Quadruple Helix": toward a 21st century fractal innovation ecosystem. International Journal of Technology Management, 46(3/4), 201-234. Retrieved from: https://www.researchgate.net/publication/240295704_Mode_3' and 'Quadruple_Helix'_Toward_a_21st_century_fractal_inn ovation_ecosystem

Carayannis, E. G. \& Campbell, D. F. J. (2010). Triple Helix, Quadruple Helix and Quintuple Helix and how do knowledge, innovation and the environment relate to each other? A proposed framework for a trans-disciplinary analysis of sustainable development and social ecology. International Journal of Social Ecology and Sustainable Development, 1(1),41-69. Retrieved from: https://www.igi-global.com/article/triple-helix-quadruple-helix-quintuple/41959

Carayannis, E.G. \& Campbell, D. F. J. (2011). Open innovation diplomacy and a 21st century fractal research, education and innovation (FREIE) ecosystem: building on the Quadruple and Quintuple Helix innovation concepts and the "Mode 3" knowledge production system. Journal of the Knowledge Economy, 2(3), 327-372. Retrieved from: https://link.springer.com/article/10.1007\%2Fs13132-011-0058-3

Carayannis, E. G. \& Campbell, D. F. J. (2012). Mode 3 knowledge production in quadruple helix innovation systems. 21stcentury democracy, innovation, and entrepreneurship for development. SpringerBriefs in business (Vol. 7). Springer, New York. Retrieved from: https://www.springer.com/la/book/9781461420613

Carayannis, E. G., Campbell, David F.J. \& Orr, B.J. (2016). Democracy and environment as references for quadruple and quintuple helix innovation systems. Retrieved from: http://meetingorganizer.copernicus.org/EGU2015/EGU2015-154971.pdf Accessed: 15.04.2021.

Climate Change Performance Index (2020). Retrieved from: https://newclimate.org/wp-content/uploads/2019/12/CCPI-2020Results_Web_Version.pdf Accessed: 15.04.2021 


\section{ENTREPRENEURSHIP AND SUSTAINABILITY ISSUES}

ISSN 2345-0282 (online) http://jssidoi.org/jesi/ 2021 Volume 9 Number 1 (September) http://doi.org/10.9770/jesi.2021.9.4126)

Climate Change Performance Index (2021). Retrieved from: https://ccpi.org/download/the-climate-change-performanceindex-2021/ Accessed: 15.04.2021

Eddelani, O., El Amrani El Idrissi, N. \& Monni, S. (2019). Territorialized forms of production in Morocco: provisional assessment for an own model in gestation. Insights into Regional Development, 1(1), 6-18. http://doi.org/10.9770/IRD.2019.1.1(1)

Energy transition index (2020). World Economic Forum. Retrieved from: http://www3.weforum.org/docs/WEF_Fostering_Effective_Energy_Transition_2020_Edition.pdf Accessed: 15.04.2021

Environmental performance index report (2020). Retrieved from: https://epi.yale.edu/downloads/epi2020report20210112.pdf Accessed: 15.04.2021

Etzkowitz, H. \& Leydesdorff, L. (2000). The dynamics of innovation: from national systems and "Mode 2" to a Triple Helix of university-industry-government relations. Research Policy, 29, 109-123. https://doi.org/10.1016/S0048-7333(99)00055-4. Retrieved from: https://www.sciencedirect.com/science/article/abs/pii/S0048733399000554

European Automobile Manufacturers' Association (2019). Retrieved from: https://www.acea.be/statistics/article/interactivemap-correlation-between-uptake-of-electric-cars-and-gdp-in-EU Accessed: 15.04.2021.

European Commission (2019). The European Green Deal. Retrieved from: https://sustainabledevelopment.un.org/post2015/transformingourworld Accessed: 15.04.2021.

Eurostat. Environmental tax revenues. Retrieved from: https://ec.europa.eu/eurostat/statisticsexplained/index.php?title=Environmental_tax statistics Accessed: 15.04.2021.

Eurostat. Resource productivity and domestic material consumption (DMC). Retrieved from:

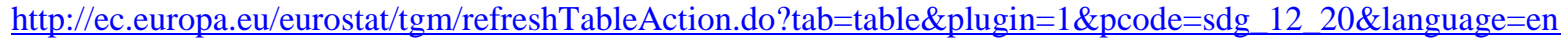

Fulai, S. (2010). Green Economy: conceptual issues. Background Paper for the UNEP Major Groups and Stakeholders Consultation on Green Economy. Geneva, pp. 1-7. Retrieved from: http://new.unep.org/civilsociety/Portals/59/Documents/GMGSF12-GE-Conceptual-Issues.pdf

Global green economy index (2016). Retrieved from: http://dualcitizeninc.com/GGEI-2016.pdf Accessed: 15.04.2021

Global innovation index (2020). Retrieved from: https://www.wipo.int/edocs/pubdocs/en/wipo_pub_gii_2020.pdf Accessed: 15.04.2021.

Kane, M. (2021). European Countries Listed By Plug-In Electric Car Market Share In Q1-Q4 2020. Retrieved from: https://insideevs.com/news/489169/european-countries-plugin-market-share-q1q4-2020/ Accessed: 6.04.2021.

Kasztelan, A. (2017). Green growth, green economy and sustainable development: terminological and relational discourse. Prague Economic Papers, 26(4), 487-499. Retrieved from: https://www.vse.cz/pep/626

Kasztelan, A. (2018). Multi-criteria analysis of green competitiveness of the EU countries. In: Proceedings of the 4th International Conference on European Integration 2018. Publisher: VSB - Technical University of Ostrava Sokolska trlda 33, 70200 Ostrava I, Czech Republic. ISBN 978-80-248-4169-4. ISSN 2571-029X. Retrieved from: https://www.researchgate.net/profile/Armand_Kasztelan/publication/325323264_Multi-

Criteria Analysis of Green_Competitiveness of the EU Countries/links/5b05a18e0f7e9b1ed7e 823cc/Multi-CriteriaAnalysis-of-Green-Competitiveness-of-the-EU-Countries.pdf

Kemp, R. \& Pearson, P. (2007). Final report MEI project about measuring eco-innovation. UM Merit, Maastricht, 32(3), 121124. 


\section{ENTREPRENEURSHIP AND SUSTAINABILITY ISSUES}

ISSN 2345-0282 (online) http://jssidoi.org/jesi/ 2021 Volume 9 Number 1 (September)

http://doi.org/10.9770/jesi.2021.9.4126)

Leal-Millán, A., \& Antonio, L. (2020). Encyclopedia of Creativity, Invention, Innovation and Entrepreneurship. Springer International Publishing, pp. 1-7. doi: 10.1007/978-1-4614-6616-1.

Razminienè, K. \& Tvaronavičienè, M. (2018). Detecting the linkages between clusters and circular economy. Terra Economicus, 16(4), 50-65. http://doi.org/10.23683/2073-6606-2018-16-4-50-65

Rosha, A. \& Lace. N. (2015). Sustainable development and behavioural patterns: to innovations through coaching. Journal of Security and Sustainability Issues, 5(2), 171-180. https://doi.org/10.9770/jssi.2015.5.2(4)

SJR - SCImago Journal \& Country Rank (2021). Retrieved from: http://www.scimagojr.com/countryrank.php?area=2300 Accessed: 15.04.2021.

Spaini, C., Markianidou, P. \& Doranova, A. (2018) EU Eco-Innovation Index (2018). Retrieved from: https://ec.europa.eu/environment/ecoap/scoreboard Accessed: 17.06.2020.

Strielkowski, W., Lisin, E. \& Tvaronavičienè, M. (2016). Towards energy security: sustainable development of electrical energy storage. Journal of Security and Sustainability, 6(2), 43-52. http://dx.doi.org/10.9770/jssi.2016.6.2(4)

Sunina, L. \& Rivza, B. (2016). The quintuple helix model: way of regional development centres in Latvia to smart public administration. In: Research for Rural Development: annual 22nd international scientific conference proceedings, Jelgava, Latvia, May 18-20, 2016. Jelgava, 2016. Vol. 2, pp. 135-142. Retrieved from: http://llufb.llu.lv/conference/Research-forRural-Development/2016/LatviaResRuralDev_22nd_vol2-135-142.pdf

Swart, J. \& Groot, L. (2020). Sustainable development: The transition to the green economy. Quality - Access to Success, 15(suppl. 1), 129-133.

The Economist Intelligence Unit: Democracy index (2019). Retrieved from: https://www.in.gr/wpcontent/uploads/2020/01/Democracy-Index-2019.pdf

The future of eco-innovation: The role of business models in green transformation OECD background paper. Retrieved from: https://www.eco-innovation.eu Accessed: 17.06.2020.

The global innovation index report (2019). Retrieved from: https://www.ifpma.org/wpcontent/uploads/2019/07/wipo_pub_gii_2019.pdf Accessed: 15.04.2021.

The global sustainable competitiveness index (2020). Retrieved from: https://solability.com/global-sustainablecompetitiveness-index/the-global-sustainable-competitiveness-index-2020 Accessed: 15.04.2021.

The travel \& tourism competitiveness report. World economic forum (2019). Retrieved from: https://www.weforum.org/reports/the-travel-tourism-competitiveness-report-2019 Accessed: 15.04.2021.

Tvaronavičienė, M. (2017). Clusters, innovations and energy efficiency: if relationship could be traced. Marketing and Management of Innovations, 2, 382-391. http://doi.org/10.21272/mmi.2017.2-35

Tvaronavičienè, M. (2018). Towards sustainable and secure development: energy efficiency peculiarities in transport sector. Journal of Security and Sustainability. Issues 7(4), 719-725. https://doi.org/10.9770/jssi.2018.7.4(9)

Tvaronavičienė, M., Mačiulis, A., Lankauskienė, T., Raudeliūnienė, J. \& Dzemyda, I. (2015). Energy security and sustainable competitiveness of industry development. Economic Research = Ekonomska istraživanja, 28(1), 502-516. http://dx.doi.org/10.1080/1331677X.2015.1082435

UNEP (2010). Green economy: driving a green economy through public finance and fiscal policy reform. Working Paper, v. 1.0. Retrieved from: http://www.greenfiscalpolicy.org/wp-content/uploads/2013/08/Driving-a-Green-Economy-ThroughPublic-Finance-and-Fiscal-Policy-Reform.pdf Accessed: 15.04.2021. 


\section{ENTREPRENEURSHIP AND SUSTAINABILITY ISSUES}

ISSN 2345-0282 (online) http://jssidoi.org/jesi/ 2021 Volume 9 Number 1 (September)

http://doi.org/10.9770/jesi.2021.9.4126)

UNEP (2011). Towards a green economy: pathways to sustainable development and poverty eradication. Retrieved from: https://sustainabledevelopment.un.org/content/documents/126GER_synthesis_en.pdf Accessed: 15.04.2021.

World Economic Forum: The Global Competitiveness Report (2019). Retrieved from: http://www3.weforum.org/docs/WEF_TheGlobalCompetitivenessReport2019.pdf Accessed: 15.04.2021.

World Energy Council: country's profile. (2019). Retrieved from: https://trilemma.worldenergy.org/\#!/energy-index Accessed: 15.04.2021

World Press Freedom Index (2020). Reporters without borders. Retrieved from: https://rsf.org/en/ranking Accessed: 15.04.2021.

\section{Appendix 1. Indicators used for each of the subsystems of the Quintuple Helix:}

Subsystem 1. Education:

S_l_1 Research institutions prominence 0-100 (best) (Global competitiveness report (further - GCR) 2019);

S_1_2 Scientific publications score (GCR, 2019);

S_l_3 Gross expenditure on R\&D, \% of GDP (Global Innovation Index, 2020);

S_l_4 Total number of documents in Scopus, Environmental science, cumulative, 1996 - 2019 (SJR — SCImago, 2021);

S_1_5 Citable documents, 1996 - 2019 (SJR - SCImago, 2021);

S_1_6 Citations (SJR - SCImago, 2021);

S_1_7 Self-citations (SJR - SCImago, 2021);

S_l_8 Citations per document (SJR - SCImago, 2021);

S_1_9 h-index, (SJR - SCImago, 2021);

S_l_10 Patents by origin/bn PPP\$ GDP (Global Innovation Index Report, 2020); **

Subsystem 2. Economic aspects:

S_2_l GDP per unit of energy use (Global Innovation Index Report, 2020);

S_2_2 ISO 14001 environmental certificates per bn PPP\$ GDP (Global Innovation Index Report, 2020);

S_2_3 Resource efficiency index (The global sustainable competitiveness index, 2020)**;

S_2_4 Greenhouse gas emissions score (Climate Change Performance Index, 2021);

$S \_2 \_5$ Share of renewable energy in gross final energy consumption by sector, \% (Eurostat, 2019)

$S \_2 \_6$ The global sustainable competitiveness index (2020**;

S_2_7 Circular material use rate, \% of material input for domestic use (Eurostat, 2019)**;

S_2_8 Efficiency sectors (Global Competitiveness Report, 2019);

S_2_9 Growth of innovative companies 1-7 (best) (Global Competitiveness Report, 2019);

S_2_10 Energy transition index (Energy transition index 2020 by World Economic Forum);**

Subsystem 3. Political system:

S_3_1 Stringency of environmental regulations, index (Travel and Tourism Competitiveness Report, 2019);

S_3_2 Enforcement of environmental regulations, index (Travel and Tourism Competitiveness Report, 2019);

S_3_3 Environment-related treaties in force count (out of 29 possible) (Global Competitiveness Report, 2019);

S_3_4 Climate policy, index - covers both national and international climate policy performance (Climate change performance index, 2021)**;

$S \_3 \_5$ Climate Change Performance Index (Climate change performance index, 2021);

S_3_6 Environmental performance, index (Global Innovation Index, 2020);

S_3_7 Environmental tax revenues, \% of GDP (Eurostat, 2018);

S_3_8 Intellectual property protection 1-7 (best) (Global Competitiveness Report, 2019);

S_3_9 Population covered by the Covenant of Mayors for Climate \& Energy signatories - percentage of total population (Eurostat, 2019, for the UK - 2018)**;

S_3_10 Renewable energy regulation 0-100 (best) (Global Competitiveness Report, 2019). 


\section{ENTREPRENEURSHIP AND SUSTAINABILITY ISSUES}

ISSN 2345-0282 (online) http://jssidoi.org/jesi/

2021 Volume 9 Number 1 (September)

http://doi.org/10.9770/jesi.2021.9.4126)

Subsystem 4. Civil society:

S_4_l Attitude of European citizens towards the environment - percentage of population who consider environmental issues to be important (Eurobarometer, 2017)**;

S_4_2 World Press Freedom Index (Reporters without borders, 2020*;

$S \_4 \_3$ Democracy index (The Economist Intelligence Unit, 2020);

S_4_4 Civil liberties (The Economist Intelligence Unit, 2020)**;

S_4_5 Social Capital Index (The global sustainable competitiveness index, 2020)**;

S_4_6 Incidence of corruption 0-100 (best), (Global Competitiveness Report 2019);

S_4_7 Internet users \% of adult population, (Global Competitiveness Report, 2019).

S_4_8 People at risk of poverty or social exclusion, Eurostat (2019), except for Ireland, Italy, the UK (2018)**;

S_4_9 Share of busses and trains in total passenger transport, \% of total inland passenger-km (Eurostat, 2018)**;

S_4_10 Females employed with advanced degrees, \% (Global Innovation Index, 2020)**.

Subsystem 5. Natural environment:

S_5_1 Environmental performance index (Environmental performance index report, 2020)**;

$S \_5 \_2$ Air quality (Environmental performance index report, 2020)**;

S_5_3 Water resources (Environmental performance index report, 2020)**;

S_5_4 Biodiversity and habitat (Environmental performance index report, 2020)**;

S_5_5 Forest cover change, \% (The Travel \& Tourism Competitiveness Report, 2019)*;

S_5_6 Wastewater treatment, \% of total (The Travel \& Tourism Competitiveness Report, 2019);

S_5_7 Total protected areas, \% of territory (The Travel \& Tourism Competitiveness Report, 2019);

S_5_8 Natural capital (The Global Sustainable Competitiveness Index, 2020)**;

S_5_9 Ecological sustainability, index (Global Innovation Index Report, 2020);

S_5_10 Agriculture (Environmental performance index report, 2020)**.

* a negative indicator (the lower it is - the better the situation for sustainable development is);

** new indicator as compared with the first stage (O. Lavrinenko et al., 2019) of the research.

\section{Acknowledgements}

This article is published within the research project of Daugavpils University "Comparative analysis of the level of green economy development in Latvia and Lithuania from 2000 to 2020”, Nr. 14-95/2021/14 


\section{ENTREPRENEURSHIP AND SUSTAINABILITY ISSUES}

ISSN 2345-0282 (online) http://jssidoi.org/jesi/ 2021 Volume 9 Number 1 (September)

http://doi.org/10.9770/jesi.2021.9.4126)

Oleg RYBALKIN is Phd pretendent in Econimics of Daugavpils University. His research interests: regional economics, sustainable development, green economy.

ORCID ID: https://orcid.org/0000-0002-7310-4594

Olga LAVRINENKO is Dr. oec, Leading researcher at the Institute of Humanities and Social Sciences of Daugavpils University, Latvia. She has status of experts of the Latvian Council of Science in the field of economics and entrepreneurship. Her research interests: regional economics, sustainable economic development.

ORCID ID: https://orcid.org/0000-0001-7383-3749

Svetlana IGNATJEVA is Dr. phys. Head of Computer Science Department of Daugavpils University, gives lectures and participates in research at Tyumen State University as a visiting foreign specialist. Research interests: development and adaptation of questionnaires; collection, analysis and data processing using Data Mining methods.

ORCID ID: https://orcid.org/0000-0002-3608-8409

Alina DANILEVIČA is Dr.oec, Researcher at the Institute of Humanities and Social Sciences of Daugavpils University, Latvia. She has the status of Expert of the Latvian Council of Science in the fields of economics and entrepreneurship, sociology and social work. Her research interests: regional economics, investments, investment climate (entrepreneurial enviroment).

ORCID ID: https://orcid.org/0000-0002-2749-2725

Make your research more visible, join the Twitter account of ENTREPRENEURSHIP AND SUSTAINABILITY ISSUES: @Entrepr69728810

Copyright (C) 2021 by author(s) and VsI Entrepreneurship and Sustainability Center

This work is licensed under the Creative Commons Attribution International License (CC BY).

http://creativecommons.org/licenses/by/4.0/

cc) (i) Open Access 